\title{
P02.21. Short- and long-term effects of expressive writing in patients with renal cell carcinoma
}

\author{
L Cohen*, N Tannir, E Jonasch, L Pisters, S Matin, A Spelman, Q Wei, C Wood \\ From International Research Congress on Integrative Medicine and Health 2012 \\ Portland, Oregon, USA. 15-18 May 2012
}

\section{Purpose}

Most previous research examining the efficacy of brief expressive writing interventions have used small sample sizes and followed people for no more than 3 months. We conducted a large randomized trial to examine an emotion-based writing intervention for patients with renal cell carcinoma and followed them for 10 months after the end of the writing sessions.

\section{Methods}

Two hundred patients with renal cell carcinoma were randomly assigned to either an expressive writing group (EW) or a neutral writing group (NW) and asked to write on four separate occasions over 10 days for a maximum of 20 minutes at each writing session. Patients completed the MD Anderson Symptom Inventory (MDASI), Brief Fatigue Inventory, SF-36, IES, CES-D, and PSQI at baseline and then again 1 and 10 months after the writing sessions.

\section{Results}

The mean age of the participants was 58 (range 34-82 years), $41 \%$ were women, and $46 \%$ had advanced disease. Examination of group differences 1 month after the writing sessions, controlling for the respective baseline measure, revealed lower IES scores for the EW group (intrusive thoughts: EW, $5.0 \mathrm{v} \mathrm{NW}, 7.2$; $\mathrm{p}<.02$; avoidance behaviors: EW, 6.3 v NW, 8.7; p<.07). At the 10 month time point, the EW group reported lower MDASI interference scores (symptoms interfering with QOL) (EW: 6.4 v NW: 9.9; $\mathrm{p}<.04)$, higher levels of SF-36 Role Physical scores (EW: $69.6 \mathrm{v}$ NW: 54.0; $\mathrm{p}<.02$ ), and fewer sleep disturbances (subscale of the PSQI; EW: 1.4 v NW: 1.6; $\mathrm{p}<.05)$. Means for the other SF-36 subscales at 10 months were in the expected direction, but did not reach statistical

The University of Texas MD Anderson Cancer Center, Houston, USA significance. There were no group differences for CES-D or fatigue scores at any time point.

\section{Conclusion}

These findings indicate expressive writing leads to shortterm reduction in intrusive thoughts about the cancer experience and results in long-term improvement in aspects of quality of life.

Published: 12 June 2012

doi:10.1186/1472-6882-12-S1-P77

Cite this article as: Cohen et al:: P02.21. Short- and long-term effects of expressive writing in patients with renal cell carcinoma. BMC Complementary and Alternative Medicine 2012 12(Suppl 1):P77.
Submit your next manuscript to BioMed Central and take full advantage of:

- Convenient online submission

- Thorough peer review

- No space constraints or color figure charges

- Immediate publication on acceptance

- Inclusion in PubMed, CAS, Scopus and Google Scholar

- Research which is freely available for redistribution
() Biomed Central 